\title{
PUTUSAN HAKIM ATAS PERCERAIAN SALAH SATU PIHAK GAIB DAN IMPLIKASINYA TERHADAP PARA PIHAK DI PENGADILAN AGAMA LIMBOTO
}

\author{
Nurhayati M. Hasan dan Ajub Ishak \\ Email:yani.janshen@gmail.com
}

\begin{abstract}
ABSTRAK
Proses perceraian dengan salah satu pihak gaib ini, dibedakan dalam proses pemanggilan pihak gaib melalui mass media yang tidak secara langsung kepada pihak yang gaib, namun proses persidangannya tetap dilaksanakan sama dengan cerai pada umumnya. Dengan demikian penelitian ini dilakukan untuk mengetahui bagaimana proses sidang cerai gaib dan implikasinya terhadap pihak berperkara di Pengadilan Agama.

Tesis ini merupakan kajian pustaka, yaitu penelitian dengan melakukan telaah terhadap putusan cerai gaib yang telah berkekuatan hukum tetap di wilayah Pengadilan Agama Limboto. Menggunakan analisis kualitatif, dengan mengumpulkan data-data didalami, ditelaah, dikaji dan dipahami dengan cara dianalisis dan disimpulkan untuk mendapatkan keakuratan data yang diperoleh. Menggunakan pendekatan yuridis sosiologis yang berusaha untuk menemukan, mengungkap dan menggambarkan fenomena hukum yang terjadi dalam persidangan, pertimbangan majelis hakim dalam memutuskan perkara cerai gaib dan realitas yang terjadi dalam masyarakat khususnya dalam perkara cerai gaib. Melalui proses wawancara, studi dokumentasi, pengolahan dan analisis data.

Berdasarkan hasil penelitian, ditemukan hal-hal yang terjadi dalam perceraian gaib, diantaranya keberadaan pihak yang digaibkan maupun dalam persidangan dan putusan cerai gaib yang telah berkekuatan hukum tetap, namun ada kelemahan dalam proses pembuktiannya dihadapan sidang, sehingga putusan hakim ini mampu memberikan implikasi kepada para pihak yang berperkara. Dengan demikian hal ini harus mendapatkan perhatian serius dari pemerintah dan aparat penegak hukum yang terkait untuk memperbaiki aturan yang telah ada demi masa depan anak bangsa, dan keteraturan proses pelaksanaan sistem peradilan agama, seharusnya ada aturan yang mengatur secara khusus tentang proses persidangan cerai gaib, yang dibedakan dengan proses cerai biasa.
\end{abstract}

Kata Kunci: Putusan, Cerai Gaib, Dan Implikasi 


\section{A. Pendahuluan}

Gugatan cerai antara suami istri yang beragama Islam, pada dasarnya merujuk pada pasal 73 Undang-Undang Nomor 7 Tahun 1989 tentang Peradilan Agama sebagaimana telah di ubah dengan Undang-Undang Nomor 3 Tahun 2006 dan perubahan kedua yaitu Undang-Undang Nomor 50 Tahun 2009 perubahan atas Undang-Undang Nomor 7 Tahun 1989 tentang Peradilan Agama: ${ }^{1}$

1. Gugatan perceraian diajukan oleh

istri atau kuasanya kepada Pengadilan yang daerah hukumnya

meliputi tempat kediaman penggugat, kecuali apabila penggugat dengan sengaja meninggalkan tempat kediaman bersama tanpa izin tergugat.

2. Dalam hal penggugat bertempat kediaman di luar negeri, gugatan

perceraian diajukan kepada Pengadilan yang daerah hukumnya meliputi tempat kediaman tergugat.

3. Dalam hal penggugat dan tergugat bertempat kediaman di luar negeri, maka gugatan diajukan kepada Pengadilan yang daerah hukumnya meliputi tempat perkawinan mereka

dilangsungkan atau kepada Pengadilan Agama Jakarta Pusat.

Sejalan dengan apa yang diatur dalam

UU Peradilan Agama, Instruksi Presiden No.1 Tahun 1991 tentang Kompilasi Hukum Islam (KHI) juga mengatur bahwa gugatan perceraian diajukan oleh istri atau kuasanya pada Pengadilan Agama, yang daerah hukumnya mewilayahi tempat tinggal penggugat kecuali istri meninggalkan tempat kediaman tanpa izin suami. ${ }^{2}$ Dimanapun keberadaan penggugat atau tergugat tidak diketahui keberadaannya, UU Peradilan

Agamadan KHI telah mengatur bahwa gugatan cerai tetap diajukan kepada Pengadilan Agama yang daerah hukumnya meliputi tempat kediaman penggugat (istri).

Mengenai gugatan kepada suami gaib (tidak diketahui keberadaannya) diatur juga dalam Pasal 20 ayat (2) Peraturan Pemerintah Nomor 9 Tahun 1975 tentang Pelaksanaan Undang-Undang Nomor 1 Tahun 1974 tentang Perkawinan: "Dalam hal tempat kediaman tergugat tidak jelas atau tidak diketahui atau tidak mempunyai tempat

\footnotetext{
Agama.

${ }^{1}$ Republik Indonesia, Undang-Undang Nomor 7 Tahun 1989 Tentang Peradilan

${ }^{2}$ Republik Indonesia, Instruksi Presiden Nomor 1 Tahun 1991 Tentang Kompilasi Hukum Islam Di Indonesia.
} 
kediaman yang tetap, gugatan perceraian diajukan kepada Pengadilan di tempat kediaman penggugat". 3

Sementara dalam Pasal 139 KHI dijelaskan bahwa jika tempat kediaman tergugat (suami) tidak jelas atau tidak mempunyai tempat kediaman yang tetap,panggilandilakukan dengancara menempelkan gugatan pada papan pengumuman di Pengadilan Agama dan mengumumkannya melalui satu atau beberapa surat kabar atau media lain yang ditetapkan oleh Pengadilan Agama. Dalam hal sudah dilakukan panggilan dan tergugat atau kuasanya tetap tidak hadir, gugatan diterima tanpa hadirnya tergugat, kecuali apabila gugatan itu tanpa hak dan tidak beralasan. Gugatan cerai yang semacam ini diterima tanpa hadirnya tergugat, dan akan diputus verstek (putusan yang dijatuhkan apabila tergugat tidak hadir atau tidak juga mewakilkan kepada kuasanya untuk menghadap meskipun ia sudah dipanggil dengan resmi dan patut). Apabila tergugat tidak mengajukan upaya verzet (perlawanan) terhadap putusan verstek itu, maka putusan tersebut dianggap sebagai putusan yang berkekuatan hukum tetap.

Perceraian salah satu pihak gaib seperti ini biasamya istri atau penggugat yang hendak mengajukan gugatan cerainya kepada pengadilan agama sering terkendala dengan keberadaan suaminya yang tidak lagi diketahui keberadaannya. Padahal dalam perjalanan rumah tangganya banyak yang sering tersiksa dengan kejadian semacam ini, yang paling merasakan adalah sang istri yang ditinggalkan dengan ketidakjelasan statusnya, sudah tidak dinafkahi, diabaikan dan bahkan ditelantarkan dengan kondisi kehidupan yang cukup memprihatinkan oleh karena harus berjuang sendiri untuk memenuhi kebutuhan hidupnya. Walaupun begitu dalam perceraian salah satu pihak gaib adapula pihak suami atau pemohon yang juga mendapatkan perlakuan yang sama, seperti suami yang tidak lagi dihargai, istri yang sudah memiliki pria idaman lain, suami dalam kondisi sakit yang tidak mampu lagi bekerja dan bahkan suami yang ditinggalkan tanpa kejelasan status oleh istrinya bersama dengan anak-anaknya dan tidak lagi diketahui keberadaannya.

Sidang perceraian gaib hanyalah berlaku untuk perceraian agama Islam untuk situasi dimana si tergugatnya tidak diketahui alamat atau keberadaannya. Seringkali situasi di atas terjadi dimana si suami atau si istri telah lama meninggalkan pasangannya bertahun-tahun sehingga ia tidak dapat diketahui lagi keberadaannya. Jika demikian

\footnotetext{
${ }^{3}$ Republik Indonesia. Peraturan Pemerintah Nomor 9 Tahun 1975 tentang Pelaksanaan Undang-Undang Nomor 1 Tahun 1974 tentang Perkawinan.
} 
maka si penggugat tetap dapat ajukan gugatan cerai dengan cara perceraian dengan salah satu pihak gaib. Harapan dari pada sidang cerai dengan pihak gaib ini pada dasarnya untuk menjamin keselamatan dari pada nasib salah satu pihak yang ditinggakan serta memperjelas status hukum dari pihak yang ditinggalkan.

Kenyataannya di masyarakat khususnya di Kabupaten Gorontalo yang merupakan wilayah hukum dari Pengadilan Limboto, hal ini sering menimbulkan masalah dikemudian hari, terkadang ada istri yang telah ditinggalkan selama bertahun-tahun tanpa status dan kabar yang jelas dari sang suami yang sah, menyebabkan istri mencari ketenangan dengan pria lain yang belum menjadi suami sahnya. Ada juga yang hanya berpura-pura tidak mengetahui lagi keberadaan suaminya, walaupun alasan cerai dari penggugat itu cukup kuat. Selain itu, ada yang mengajukan perceraian dalam kurun waktu kurang dari 2 tahun, padahal seharusnya dalam alasan perceraian minimal 2 tahun berturut-turut ditinggalkan baru bisa mengajukan perceraian, ada pula yang mengajukan perceraian setelah lebih dari 10 tahun nanti diajukan setelah ada yang sudah ingin menikah dengan dirinya.

Data perkara perceraian di Pengadilan Agama Limboto menunjukan bahwa tingkat cerai gaib sangat tinggi terjadi di Pengadilana Agama Limboto, dan yang menjadi dasar penelitian sebanyak 32 perkara dari tahun 2014 s/d 2016, dengan jumlah yang berbedabeda di tahun 2014 berjumlah 17 perkara, tahun 2015 berjumlah 8 perkara, dan di tahun 2016 berjumlah 7 perkara. Dari total perkara yang masuk sejak tahun 2014 sampai dengan 2016, ada 31 perkara yang diputus secara verstek dan telah berkekuatan hukum tetap, karena tidak dihadiri oleh salah satu pihak dan tidak ada upaya verzet dari pihak yang di gaibkan. Sementara 1 putusan lainnya dikabulkan dengan dihadiri oleh termohon dan telah berkekuatan hukum tetap lewat keputusan majelis hakim di Pengadilan Agama Limboto tanpa ada upaya banding dari pihak termohon. Meskipun syarat dan ketentuan dari pengadilan yang berwenang telah terpenuhi oleh pihak yang berperkara dan proses pemanggilan pihak telah dilakukan sesuai dengan prosedurnya, namun tetap saja segala keputusannya ada ditangan hakim, sehingga apapun putusan hakim pada akhir sidang merupakan putusan yang berkekuatan hukum tetap.

Berdasarkan fakta-fakta yang telah diungkapkan maka hal ini sangat layak diteliti untuk mengetahui bagaimana putusan hakim atas cerai salah satu pihak gaib dan implikasi terhadap para pihak berperkara di Pengadilan Agama Limboto.

Berdasarkan uraian latar belakang diatas dapat diangkat permasalahan yang akan diteliti sebagai berikut: 
1. Bagaimana proses penyelesaian perceraian salah satu pihak gaib dalam putusan hakim di Pengadilan Agama Limboto ?

2. Bagaimana implikasi putusan terhadap para pihak yang berperkara di Pengadilan Agama Limboto? 


\section{Metode Penelitian}

\section{Jenis Penelitian}

Penelitian ini menggunakan jenis penelitian kualitatif yaitu penelitian yang bermaksud untuk memahami fenomena tentang apa yang dilalui oleh subyek penelitian misalnya perilaku, persepsi,

motivasi, tindakan, dll, secara holistik dan dengan cara deskripsi dalam bentuk kata-kata dan bahasa, pada suatu konteks khusus yang alamiah dan dengan memanfaatkan berbagai metode ilmiah. ${ }^{4}$ Yang paling pokok dikaji dalam penelitian ini adalah menggambarkan proses pelaksanaan sidang perceraian salah satu pihak gaib sampai dengan putusan dan melihat bagaimana implikasinya putusan hakim terhadap para pihak berperkara di Pengadilan Agama Limboto, sehingga penelitian ini mampu untuk menjawab masalah yang diteliti.

\section{Pendekatan Penelitian}

Pendekatan penelitian yang digunakan dalam penelitian ini adalah pendekatan yuridis sosiologis. Penelitian ini melihat bagaimana interaksi sosial dan pertimbangan putusan hakim yang terjadi dalam proses pemeriksaan sidang cerai gaib di Pengadilan Agama Limboto, dengan mengaitkan antara fakta sosial yang terjadi dengan tata aturan hukum sesungguhnya yang berlaku dalam proses beracara di lingkungan Peradilan Agama.

\section{Lokasi Penelitian}

Penelitian ini dilakukan di Pengadilan Agama Limboto dengan wilayah hukumnya berada di dua Kabupaten yaitu Kabupaten Gorontalo dan Kabupaten Gorontalo Utara, namun penelitian ini di fokuskan untuk perkara yang berada di wilayah Kabupaten Gorontalo. Adapun alasan pemilihan lokasi penelitian ini karena Pengadilan Agama Limboto merupakan salah satu Pengadilan Agama yang ada di wilayah Provinsi Gorontalo dengan jumlah perkara terbanyak di setiap tahunnya. Sementara Perkara cerai gaib juga merupakan salah satu perkara yang disidangkan di Pengadilan Agama Limboto dengan jumlah perkara yang cukup banyak diajukan. Sehingga dengan pertimbangan ini dapat dengan mudah untuk menemukan data-data yang dibutuhkan dan mudah untuk menjangkau lokasi penelitian.

${ }^{4}$ Lexy J. Moleong, Metodologi Penelitian Kualitatif, (Bandung: PT Remaja Rosdakarya Offset, 2013), cet. 31. 


\section{Sumber Data}

Berkaitan dengan permasalahan dan pendekatan masalah yang digunakan dalam penelitian ini menggunakan sumber data kepustakaan. Sedangkan jenis datanya adalah data sekunder yaitu data yang diperoleh melalui bahan pustaka dengan cara mengumpulkan dari berbagai sumber bacaan yang berhubungan dengan masalah yang diteliti dan data primer yaitu data pendukung yang diperoleh langsung dari obyek penelitian melalui proses wawancara.

\section{Metode Pengolahan dan Analisa Data}

Data yang telah diperoleh melalui hasil pengumpulan data, selanjutnya dilakukan pemeriksaan data dan pengkajian lebih dalam untuk menjamin keakuratan data dan dapat dipertanggung jawabkan sesuai dengan aturan, teori dan konsep. Setelah semua data terkumpul kemudian dilakukan pembahasan, pemeriksaan dan pengelompokan sesuai dengan masalah yang dibahas, kemudian diolah menjadi data informasi. Hasil analisa data inilah yang telah digunakan dalam menjawab persoalan dalam rumusan masalah, sehingga dengan hasil penelitian ini dapat ditemukan hal-hal baru yang belum pernah ditemukan sebelumnya dan semakin memperluas wawasan, khususnya dalam bidang hukum keluarga, yang kemudian dilakukan secara kualitatif dan terakhir ditarik kesimpulan sehingga diperoleh data yang jelas mengenai jawaban terhadap permasalahan yang diteliti. 


\section{Pembahasan}

\section{Proses Penyelesaian Cerai Gaib Di Pengadilan Agama Limboto}

Perceraian bukanlah perkara yang dilarang dalam Islam, tetapi merupakan perbuatan yang dibenci oleh Allah SWT. Perceraian pada dasarnya merupakan jalan terakhir apabila sudah tidak ada lagi jalan keluar yang lain dalam mempertahankan ikatan perkawinan. Dasar hukum perceraian sudah sangat jelas dalam tata aturan Hukum Perdata Islam di Indonesia antara lain dalam UU No. 1 Tahun 1974 tentang Perkawinan, Kompilasi Hukum Islam (KHI) dan UU No. 7 Tahun 1989 tentang Peradilan Agama.

Pelaksanaan pemeriksaan perkara perceraian di Pengadilan Agama umumnya sudah berjalan dengan baik, namun dalam perkara perceraian ini ada satu perkara perceraian yang sedikit berbeda dengan perkara perceraian lainnya, yaitu perkara cerai gaib dalam hal ini salah satu tergugat atau termohon dinyatakan gaib atau tidak diketahui lagi keberadaannya. Beberapa hal yang berbeda antara lain dalam proses pemeriksaannya yang lebih banyak tidak dihadiri oleh tergugat atau termohon serta dalam proses pemanggilannya yang menggunakan satu media dalam pemanggilan pihak yang dinyatakan gaib, yaitu melalui siaran Radio RRI Gorontalo.

Berdasarkan hasil penelitian yang dilakukan di Pengadilan Agama Limboto, dalam hal realitas penyelesaian cerai gaib di Pengadilan Agama Limboto menemukan beberapa hal yang menjadi titik kritis dalam penelitian ini. Dalam data perkara perceraian gaib di Pengadilan Agama Limboto, sebanyak 32 kasus yang berhasil dilakukan telaah terhadap putusan hakim yang telah berkekuatan hukum tetap. Sehingga menemukan beberapa fakta yang terdapat dalam putusan hakim atas cerai gaib yaitu:

\section{Alat Bukti Saksi Persidangan Lemah Alat bukti merupakan suatu hal berupa}

Bentuk dan jenis yang dapat membantu dalam hal memberi keterangan dan penjelasan tentang sebuah masalah perkara untuk membantu penilaian hakim di dalam pengadilan. Jadi, para pihak yang berperkara hanya dapat membuktikan kebenaran dalil gugat dan dalil bantahan maupun fakta-fakta yang mereka kemukakan dengan jenis atau bentuk alat bukti tertentu. Hukum pembuktian yang berlaku di Indonesia sampai saat ini masih berpegang kepada jenis dan alat bukti tertentu saja.

Adapun alat bukti dalam Hukum Acara Perdata yang tercantum dalam Pasal 1866 B.W., adalah, alat bukti tertulis (Surat), alat bukti saksi, bukti persangkaan, bukti pengakuan, dan bukti sumpah. Kelima alat bukti ini merupakan alat bukti yang sah dalam perkara perdata di Pengadilan Agama yang sampai dengan saat ini masih tetap digunakan, termasuk dalam perkara perdata di Pengadilan Agama Limboto, juga masih 
tetap menggunakan kelima alat bukti dalam mempertimbangkan dan memutuskan suatu perkara.

Berdasarkan hasil penelitian yang dilakukan dengan menelaah putusan hakim yang telah berkekuatan hukum tetap di Pengadilan Agama Limboto, menemukan fakta bahwa dari 32 perkara cerai gaib yang disidangkan, semuanya menggunakan jenis alat bukti yang sah berdasarkan pasal 1866 B.W. Namun, yang menjadi titik kritis dalam penelitian ini adalah bahwa beberapa alat bukti yang disampaikan di hadapan sidang cerai gaib di Pengadilan Agama Limboto dalam hal ini bukti saksi yang berasal dari luar keluarga bahkan ada yang tidak begitu bersentuhan langsung dengan penggugat atau tergugat. Antara lain menghadirkan tetangga, pemerintah desa dan teman penggugat/pemohon yang rata-rata menyampaikan kesaksian yang tidak menguatkan isi gugatan atau permohonan, memberikan kesaksian hanya berdasarkan apa yang pernah diceritakan oleh penggugat/pemohon dan bahkan tidak mengetahui pasti pokok perkara yang disidangkan. Dari 32 putusan cerai gaib terdapat 14 putusan yang saksinya dapat dianggap lemah dalam memberikan keterangannya.

\section{Alat Bukti Surat lemah}

Nilai pembuktian dalam hukum acara perdata berbeda dengan nilai pembuktian pada perkara pidana. Dalam hukum acara perdata, setiap alat bukti memiliki batas minimal pembuktian yang berbeda antara satu dengan yang lain. Begitu juga dengan nilai kekuatan yang melekat pada masing-masing alat bukti, tidak sama. Adapun klasifikasi alat bukti tertulis atau surat diklasifikasikan sebagai berikut:

a. Akta otentik,

b. Akta bawah tangan, dan

c. Akta sepihak atau pengakuan sepihak.

Berdasarkan sumber aslinya, terdapat perbedaan nilai kekuatan pembuktian yang melekat pada masing-masing jenis akta. Jadi, meskipun ketiga jenis alat bukti itu samasama berada dan digolongkan sama-sama pada satu rumpun, namun kekuatan pembuktian yang melekat pada masing-masing akta tidak sama, tetapi berbeda antara satu dengan yang lain sesuai dengan spesifikasi bentuknya. Namun demikian dimungkinkan pada ketiga jenis itu akan melekat nilai kekuatan pembuktian yang sama bobotnya, apabila terpenuhi syarat-syarat tertentu.

Alat bukti surat merupakan bukti yang sangat kuat dalam proses peradilan baik dalam peradilan pidana maupun perdata, termasuk dalam perkara perceraian gaib. Berdasarkan hasil penelitian yang dilakukan di Pengadilan Agama Limboto dengan menelaah 32 putusan yang telah berkekuatan hukum tetap atas cerai gaib, menunjukan 
bahwa hanya ada satu bukti surat yang diungkapkan dalam fakta persidangan dan menjadi dasar pertimbangan hukum majelis hakim, yaitu alat bukti buku nikah atau bukti kutipan akta nikah yang disahkan oleh KUA tempat menikah.

Melihat perkara ini merupakan perkara cerai gaib yang menunjukan bahwa salah satu pihak dalam hal ini tergugat/termohon merupakan orang yang tidak diketahui lagi keberadaannya, sehingga hal ini membedakan dengan perkara cerai biasa yang diketahui keberadaan tergugat atau termohon, maka ada baiknya bukti surat harus ditambah untuk memperkuat dalil gugatan/permohonan penggugat atau pemohon. Seperti dapat menunjukan surat keterangan bahwa benarbenar tergugat/termohon sudah tidak diketahui lagi keberadaannya baik didalam maupun diluar wilayah Republik Indonesia. Sebab dalam dalil gugatan/permohonan, keterangan saksi dan pertimbangan hukum majelis hakim, menunjukan ketidak beradaan salah satu pihak namun tidak disertai bukti yang jelas, yang menguatkan bukti itu hanyalah pengakuan salah satu pihak (penggugat/pemohon) dan pengakuan dari 2 orang saksi yang sebagian justru lemah dalam pengakuannya.

\section{Pertimbangan Hukum Majelis Hakim Lemah}

Pertimbangan hukum majelis hakim pada dasarnya, merupakan pertimbangan hukum yang tidak dapat di ganggu gugat oleh siapapun apabila putusannya telah berkekuatan hukum tetap, namun demi untuk membuktikan kekuatan dari pada pertimbangan putusan majelis hakim terhadap cerai gaib yang berbeda dengan proses percearain lainnya, hal ini layak untuk dijadikan sebagai objek penelitian untuk menambah wawasan keilmuan.

Berdasarkan penelitian yang telah dilakukan terhadap 32 putusan cerai gaib terdapat 17 putusan yang telah berkekuatan hukum tetap yang pertimbangan hukumnya kuat, sementara 15 putusan lainnya menunjukan pertimbangan hukum majelis hakim yang lemah.

Pertimbangan hakim dalam perkara cerai gaib ini pada dasarnya terdapat lima dasar pertimbangan dalam memutuskan perceraian gaib:

a. Berdasarkan dilil gugatan yang diajukan penggugat;

b. Berdasarkan bukti tertulis;

c. Berdasarkan keterangan saksi;

d. Berdasarkan keyakinan hakim;

e. Dan berdasarkan hasil ijtihad hakim. 
Kelima dasar pertimbangan hakim inilah yang terdapat dalam putusan perkara cerai gaib yang telah berkekuatan hukum tetap. Dengan demikian dasar pertimbangan hakim ini harus benar-benar saling menguatkan satu dengan yang lainnya. Walaupun hakim diberikan kewenangan penuh dalam memutuskan dan bahkan putusannya disamakan dengan putusan tuhan yang tidak dapat diganggu gugat, bukan dalam arti bahwa semua putusan hakim itu sudah memiliki kebenaran yang tidak dapat dibantah lagi. Sebab, masih ada juga putusan hakim yang sering dianggap keliru, kacau, tidak sistematis, tidak efisien, sering bersifat abstrak, dan tidak adil.

Setiap putusan hakim, yang perlu diperhatikan adalah pertimbangan hukumnya, sehingga siapapun dapat menilai apakah putusan yang dijatuhkan cukup mempunyai alasan yang objektif atau tidak. Berbeda dengan apa yang ada dalam pertimbangan hukum majelis hakim pada beberapa perkara tersebut diatas yang jelas terlihat pertimbangan hukum dasarnya lemah, sebab tidak mempunyai alasan yang objektif. Alasan yang dikemukakan dalam pertimbangan hukum tidak memiliki bukti yang kuat dan dapat dipertanggung jawabkan sehingga bisa jadi dasar pertimbangan hukum ini dapat menjadi pertimbangan hukum yang lemah, mengingat perkara cerai gaib merupakan perkara yang semestinya dibedakan dengan proses pemeriksaan perkara cerai lainnya.

Adapun beberapa hal yang dapat dinilai lemah dalam pertimbangan hukum majelis hakim adalah:

a. Mempertimbangkan pernyataan saksi yang tidak berdasar sebagai dasar pertimbangan hukum.

b. Mempertimbangkan ketidakberadaan tergugat/termohon tanpa bukti tertulis dalam persidangan.

Untuk menghindari putusan yang sering dianggap seperti yang dijelaskan diatas dan dengan memperhatikan fakta-fakta yang dikemukakan tersebut dihubungkan dengan kenyataan kecakapan dan kemampuan hakim yang bersifat generalis, yakni pengetahuan yang mereka miliki pada umumnya sangat terbatas sekali, semakin cukup alasan untuk menolak putusan hakim. Namun, demi untuk keteraturan pelaksanaan putusan hakim yang lebih baik lagi maka, aturan terhadap proses cerai gaib harus diatur secara khusus, dan tidak disamakan dengan proses perceraian biasa, yang kemudian harus di sosialisasikan kepada masyarakat secara luas, agar masyarakat yang ingin berperkara melalui proses perceraian gaib dapat terbantu dengan adanya sedikit pengetahuan yang diberikan dan tidak meraba-raba saat proses cerai diajukan. 


\section{Implikasi Putusan Cerai Gaib Terhadap Para Pihak Di Pengadilan Agama}

\section{Limboto}

Berdasarkan hasil tealaah putusan dan penelitian yang dilakukan di Pengadilan Agama Limboto, berhasil menemukan beberapa fakta dalam hal implikasi putusan cerai gaib terhadap para pihak di Pengadilan Agama Limboto yang telah berkekuatan hukum tetap di 32 perkara perceraian gaib dari Tahun 2014 s/d 2016, yaitu:

\section{Putusan Dilakukan Secara Sepihak}

Secara syar'i perkawinan itu ialah ikatan yang menjadikan halalnya bersenangsenang antara laki-laki dengan perempuan, dan tidak berlaku dengan adanya ikatan tersebut, larangan-larangan syari'at. Selanjutnya, ikatan pernikahan merupakan ikatan yang paling utama karena berkaitan dengan dzat manusia dan mengikat antara dua jiwa dengan ikatan cinta dan kasih sayang, dan karena ikatan tersebut merupakan sebab adanya keturunan dan terpeliharanya kemaluan dari perbuatan keji.

Perkawinan juga merupakan proses menyatukan keluarga besar dari kedua belah pihak yang melakukan ikatan perkawinan. Perkawinan tidak akan bahagia, aman dan tentram ketika salah satu keluarga tidak menghendaki perkawinan tersebut, maka dengan demikian memutuskan ikatan perkawinan pun tidak hanya berbiacara sebatas pada persoalan orang perorang yang telah memiliki ikatan perkawinan tetapi juga mengaitkan keluarga besar didalamnya. Sebab, perkawinan dilakukan dengan cara yang baik, dihadiri dan disetujui oleh keluarga kedua belah pihak maka ada baiknya perceraian pun dilakukan dengan cara yang sama.

Berdasarkan hasil penelitian yang telah dilakukan di Pengadilan Agama Limboto dengan menelaah putusan dan melihat realitas yang terjadi di lapangan. Dari 32 perkara perceraian gaib, hanya ada satu kasus yang dihadiri oleh pihak termohon sementara 31 perkara lainnya tidak dihadiri oleh pihak tergugat/termohon dengan alasan yang tidak diketahui pasti meskipun sudah dipanggil secara resmi dan patut melalui mass media (RRI Gorontalo) sebanyak dua kali panggilan dengan rentan waktu selama satu bulan.

Perceraian dengan status salah satu dinyatakan gaib atau tidak diketahui lagi keberadaannya baik didalam maupun diluar wilayah Republik Indonesia, menunjukan adanya perbedaan dengan perkara perceraian seperti biasa yang dihadiri oleh kedua belah pihak maupun yang tidak dihadiri salah satu pihak (bukan gaib). Perbedaannya terletak pada proses pemanggilan yang dilakukan hanya melalui mass media (RRI Gorontalo).

Beberapa fakta yang ditemukan setelah melakukan wawancara dengan penggugat/pemohon atau keluarga pemohon/penggugat, menemukan beberapa fakta 
yang sebenarnya terjadi dalam proses cerai gaib terutama dalam proses pemanggilan dan penentuan gaibnya tergugat/termohon. Dari 32 perkara perceraian gaib yang diteliti ada 10 yang berhasil ditemui dan dilakukan proses wawancara dengan para pihak, semuanya menyampaikan bahwa ketidak tahuan terhadap proses cerai gaib, yang di dilakukan para pihak pada saat itu hanya melakukan pendaftaran cerai yang kemudian menyampaikan bahwa tergugat/termohon sudah tidak diketahui lagi keberadaannya sehingga disarankan untuk meminta surat pernyataan dari pemerintah desa bahwa tergugat/termohon sudah tidak diketahui keberadaannya.

Selain itu ditemukan pula fakta bahwa ada beberapa pihak tergugat/termohon yang sebenarnya masih dapat dideteksi keberadaannya di wilayah republik Indonesia, tetapi karena ingin mempercepat proses maka para pihak menyampaikan bahwa sudah tidak diketahui lagi keberadaan tergugat atau termohon.

Dengan demikian putusan secara verstek pada proses perceraian gaib harus ditinjau lagi efektifitasnya, apalagi kalau masih menggunakan pola pemanggilan yang tidak menjangkau secara luas. Hal ini dapat memberikan implikasi terhadap para pihak tergugat atau termohon dalam bentuk penjatuhan putusan secara sepihak tanpa pembelaan dan tanpa sepengetahuannya sama sekali, meskipun para pihak berada pada posisi yang digugat atau dimohonkan, ada baiknya juga harus didengar keterangannya, kecuali bagi yang sempat mendengar namun tidak mau mengahdiri panggilan barulah ia layak untuk mendapatkan putusan semacam ini.

2. Putusan Membebani Salah Satu Pihak Perkara cerai gaib yang ada di Pengadilan

Agama Limboto, setiap tahunnya meningkat jumlah pendaftar. Selain karena biayanya terjangkau, prosesnya cepat, dan mudah untuk dijalani oleh para pihak kemungkinan besar hal ini menjadi bahan pertimbangan untuk mengajukan cerai dengan menggaibkan salah satu pihak.

Sehingga dengan sendirinya proses peradilan yang ada di Pengadilan Agama banyak digampangkan prosesnya karena tidak memberatkan pihak, prosesnya cepat dan biaya ringan, sesuai dengan asas Peradilan Agama ditentukan berdasarkan hasil musyawarah dan perhitungan majelis hakim.

Putusan cerai gaib yang dihadiri oleh pihak termohon ini mampu memberikan implikasi kepada kedua belah pihak baik pemohon maupun termohon. Termohon dalam posisi yang dinyatakan gaib tapi nyatanya hadir dalam persidangan dengan tujuan untuk menuntut hak-haknya dan bersikeras untuk tidak ingin diceraikan, sehingga alasanalasannya sebagian dapat menjadi pertimbangan hakim dalam memutuskan perceraian. Sementara posisi pemohon yang berniat untuk bercerai dengan proses yang akan 
berjalan dengan mulus, namun nyatanya tidak dapat berjalan dengan mulus seperti yang dibayangkan, segala permohonannya dapat dibantah oleh termohon, yang pada akhirnya diputusan akhir memberikan beban yang memberatkan kepada dirinya.

\section{Kejelasan Status Perkawinan}

Berdasarkan hasil penelitian yang telah dilakukan dalam menelaah putusan dan melihat fakta di masyarakat melalui pihak yang sempat diwawancarai, dari 32 perkara yang diteliti ini pada akhirnya memiliki kejelasan status perkawinan setelah adanya putusan cerai gaib dari Pengadilan Agama Limboto yang berkekuatan hukum tetap. Putusan hakim ini sebenarnya sangat membantu melegalkan status yang sebelumnya dapat dikatakan janda atau duda illegal sebab belum memiliki status yang jelas, setelah lama ditinggalkan pasangannya, walaupun ada 5 putusan yang sebenarnya belum terlalu lama ditinggalkan pasangan (masih dibawah 2 tahun) tapi sudah mengajukan cerai dengan status pasangan yang gaib.

Kejelasan status perkawinan dari yang awalnya berstatus sebagai suami atau istri, kemudian berubah statusnya menjadi seorang janda atau duda ini, hanya dapat dilakukan di Pengadilan Agama kalau perkawinannya dilakuakan secara sah. begitu banyak para pihak dalam perkara cerai gaib ini yang hidup dalam ketidak jelasan status, ditinggalkan dalam rentan waktu yang begitu lama bahkan ada satu perkara yang merupakan perkara paling lama ditinggalkan yaitu selam 14 tahun baru diajukan, yang pada saat ditinggalkan dalam keadaan hamil anak pertama dan kemudian baru mengajukan cerai saat anaknya sudah berumur 14 tahun atau kelas 2 SMP. Bisa dibayangkan selama 14 tahun hidup dalam kesendirian tanpa status yang jelas, punya anak tapi tak punya suami apalagi perkawinan yang dilakukan pada saat itu hanya berlangsung kurang dari seminggu, sehingga dapat dipastikan penderitaan selama 14 tahun dari penggugat ini baru dapat berakhir setelah penggugat mengajukan perceraian yang akhirnya menikah dengan laki-laki lain.

Dengan demikian putusan hakim dalam perceraian gaib ini dapat berimplikasi pada para pihak terkait status perkawinannya yang akhirnya mendapatkan legalitas dari yang sebelumnya berstatus kurang jelas. Meskipun hal ini dapat memberikan implikasi kepada para pihak terhadap statusnya, maka sebaiknya para pihak yang ada dalam persidangan harus benar-benar membuktikan kebenarannya dalam proses persidangan dan putusan hakim pun harus benar-benar berdasarkan kepada keyakinan yang meyakinkan, sebab perceraian menentukan nasib daripada status seseorang. 


\section{E. Penutup}

\section{Kesimpulan}

Setelah dilakukan penelitian pada obyek penelitian dilapangan dan telaah terhadap putusan hakim yang telah berkekuatan hukum tetap di Pengadilan Agama Limboto terhadap putusan cerai salah satu pihak gaib, maka dapat disimpulkan bahwa, putusan hakim atas perceraian salah satu pihak gaib dan implikasinya terhadap para pihak di Pengadilan Agama Limboto adalah sebagai berikut:

1. Realitas penyelesaian cerai gaib dalam putusan hakim di Pengadilan Agama Limboto, berdasarkan hasil telaah putusan dan wawancara dalam proses penelitian ini berhasil menemukan beberapa fakta antara lain yaitu; alat bukti saksi dalam persidangan cerai gaib dapat dinilai lemah karena kekuatan saksi lebih banyak tidak mengetahui pokok perkara yang disidangkan, alat bukti surat lemah hal ini juga disebabkan oleh ada yang seharusnya dibuktikan dengan surat tetapi dalam proses persidangan tidak dibuktikan padahal jadi bagian dari pertimbangan majelis hakim dalam memutus perkara, kamudian yang terakhir adalah dasar pertimbangan hukum yang dinilai lemah sebab di semua kasus kesimpulan dasar pertimbangan hukum yang didasarkan atas fakta persidangan justru hanya satu poin yang dapat didukung keabsahannya dengan bukti lainnya (surat) sementara hal lainnya tidak dapat dibuktikan hanya berdasarkan fakta persidangan sementara justru hal tersebut adalah pokok perkara yang disidangkan.

2. Implikasi putusan hakim terhadap para pihak, berdasarkan hasil penelitian yang dilakukan melalui proses wawancara dan telaah putusan yang berkekuatan hukum tetap ditemukan hal-hal yang dapat memberikan implikasi terhadap para pihak yaitu; putusan hanya dilakukan secara sepihak tanpa diketahui oleh tergugat/termohon, putusan dapat dinilai membebani salah satu pihak dengan hadirnya termohon yang digaibkan dan kejelasan status perkawinan para pihak.

\section{Rekomendasi}

Untuk mewujudkan ketertiban dan ketaatan hukum dalam proses perceraian gaib ini, banyak hal yang penting untuk dibenahi dalam proses ini terutama dalam rangka perbaikan dan perubahan atas aturan yang telah berlaku, Sehingga dalam hal ini untuk mewujudkan keteraturan terhadap aturan tentang perceraian khusunya yang berstatus gaib, maka perlunya untuk memberikan rekomendasi penelitian sebagai wujud dari hasil penelitian yang telah dilakuakan antara lain: 
1. Mengingat proses perceraian merupakan sesuatu hal yang sangat sensitif terutama dalam rangka memutuskan kehidupan rumah tangga, sebaiknya proses cerai gaib ini dalam proses pemeriksaan perkara harus benar-benar dibuktikan pokok perkaranya, terutama pada beban pembuktian yang terkesan sama dengan pembuktian pada perceraian biasa, sehingga mampu mempengaruhi pertimbangan hakim dalam memutuskan. Hal ini dilakukan demi untuk memperbaiki keteraturan proses peradilan perdata, agar tidak dianggap sepeleh oleh para pihak yang menganggap mudah dalam prosesnya sehingga banyak terjadi pembohongan fakta didalam proses persidangan.

2. Hendaknya proses putusan verstek dalam sidang cerai gaib sebaiknya ditinjau kembali, karena tujuan putusan verstek yang sebenarnya tidak bersesuaian dengan alasan pertimbangan hakim. Begitu juga dengan proses pemanggilan para pihak dalam cerai gaib, penting untuk melakukan perubahan terhadap tata cara pemanggilan yang masih menggunakan pola lama yang sudah tidak sesuai dengan perkembangan zaman. Sehingga hal ini berdampak pada tidak hadirnya tergugat yang pada kenyataannya ada yang sebenarnya masih dapat dideteksi keberadaanya. Hal demikian ini justru mengakibatkan adanya putusan yang dilakukan secara sepihak yang sudah pasti dapat memberikan implikasi terhadap pihak yang merasa di rugikan dengan putusan majelis hakim.

3. Aturan terhadap proses cerai gaib sebaiknya diatur secara khusus dalam proses peradilan perdata di Pengadilan Agama, pada proses pendaftaran dan pemanggilan pihak ada perbedaan dengan proses perceraian biasa, namun dalam kenyataannya pada saat proses persidangan cerai gaib disamakan dengan proses perceraian biasa sebagaimana mestinya yang diatur dalam Undang-Undang No. 7 Tahun 1989 tentang Peradilan Agama, sehingga pada pertimbangan hakim dan putusan akhir terkesan tidak ada perbedaan dengan proses perceraian biasanya. 


\section{DAFTAR PUSTAKA}

Abdul Manan, Penerapan Hukum Acara Perdata Di Lingkungan Pengadilan Agama, (Cet. III, Yogyakarta: Kencana, 2005)

Ahmad Rofiq, Hukum Perdata Islam Di Indonesia, (Jakarta: PT. Raja Grafindo Persada, 2015).

Al Hamdani, Risalah Nikah, (Pekalongan: Raja Murah, 1980).

Amir Syarifudin, Hukum Perkawinan di Indonesia, Antara Munakahat dan Undangundang Perkawinan, (Jakarta: Pranada Media Group, 2006).

Amiruddin dan Zainal Asikin, Pengantar Metode Penelitian Hukum, (Jakarta: PT Raja Grafindo Persada, 2004).

ArisBintania, Hukum Acara Peradilan Agama Dalam Kerangka Fiqh al-Qadha, (Jakarta: PT. Raja Grafindo Persada, 2012).

Ahmad Kamil, Filsafat Kebebasan Hakim, (Jakarta: Kencana Prenada Media Grup, 2012).

Bambang Sunggono, Metodologi Penelitian Hukum, (Jakarta: PT. Raja Grafindo Persada, 2006).

Cik Hasan Bisri, Kompilasi Hukum Islam Dalam Sistem Hukum Nasional, (Jakarta: Logos, 1999)

Erfaniah Zuhria, Peradilan Agama Indonesia, Sejarah Pemikiran dan Realita, (Malang: UIN Malang Press, 2009). Cet. II.

Heriyono, Tesis: Kekerasan Dalam Rumah Tangga Sebagai Alasan Terjadinya Perceraian Menurut Undang-Undang Nomor 1 Tahun 1974 dan Kompilasi Hukum Islam, (Semarang: Universitas Diponegoro, 2009)

Ibrahim Muhammad Al-Jamal, Fikih Muslim Ibadah Mu'amalat, Alih Bahasa ZaidHusain Al-Hamid, (Jakarta: Pustaka Al- Amani, 1999).

Instruksi Presiden No. 1 Tahun 1991, Kompilasi Hukum Islam (KHI) di Indonesia.

J.C.T. Simorangkir. dkk, Kamus Hukum (Jakarta: Sinar Grafika Offset, 2013),

Lexy J. Moleong, Metodologi Penelitian Kualitatif, (Bandung: PT Remaja Rosdakarya Offset, 2013), cet. 31.

Kementerian Agama RI, Al-Qur'an dan Terjemah “Mushaf Fatimah”, Pustaka Al-Fatih, Jakarta, 2009. 
M. Abdul Mujieb, Kamus Istilah Fiqih, (Jakarta: Pustaka Firdaus, 1994).

M. Yahya Harahap, Kedudukan Kewenangan dan Acara Peradilan Agama UndangUndang Nomor 7 Tahun 1989, (Jakarta: Pustaka Kartini, 1993).

M. Yahya Harahap, Hukum Acara Perdata, (Cet. 8, Jakarta: Sinar Grafik, 2008)

Muhammad Syaifuddin, Hukum Perceraian, (Jakarta: Sinar Grafika, 2014)

Nurudin, Tesis: Undang-Undang Nomor 1 Tahun 1974 dan Peraturan Pemerintah Nomor 9 Tahun 1975 Tentang Tenggang Waktu Pemanggilan Tergugat Dalam Perkara Ghaib Perceraian Ditinjau Dari 
Jurnal Ilmiah AI-Jauhari (JIAJ)

Studi Islam dan Interdisipliner

Volume 3 No 2 September 2018

ISSN 2541-3430 E-ISSN 2541-3449 